\title{
Coordinated Induction of Plasminogen Activator Inhibitor-1 (PAl-1) and Inhibition of Plasminogen Activator Gene Expression by Hypoxia Promotes Pulmonary Vascular Fibrin Deposition
}

\author{
David J. Pinsky, Hui Liao, Charles A. Lawson, Shi-Fang Yan, Jingxian Chen, Peter Carmeliet, ${ }^{*}$ David J. Loskutoff, ${ }^{\ddagger}$ \\ and David M. Stern \\ Columbia University College of Physicians and Surgeons, New York 10032; * The Center for Molecular and Vascular Biology, University \\ of Leuven, Leuven, Belgium; and ${ }^{\ddagger}$ The Research Institute of Scripps Clinic, La Jolla, California 92037
}

\begin{abstract}
Oxygen deprivation, as occurs during tissue ischemia, tips the natural anticoagulant/procoagulant balance of the endovascular wall to favor activation of coagulation. To investigate the effects of low ambient oxygen tension on the fibrinolytic system, mice were placed in a hypoxic environment with $\mathrm{pO}_{2}<40$ Torr. Plasma levels of plasminogen activator inhibitor-1 (PAI-1) antigen, detected by ELISA, increased in a time-dependent fashion after hypoxic exposure (increased as early as $4 \mathrm{~h}, P<0.05$ vs. normoxic controls), and were accompanied by an increase in plasma PAI-1 activity by $4 \mathrm{~h}(P<0.05$ vs. normoxic controls). Northern analysis of hypoxic murine lung demonstrated an increase in PAI-1 mRNA compared with normoxic controls; in contrast, transcripts for both tissue-type plasminogen activator (tPA) and urokinase-type plasminogen activator (UPA) decreased under hypoxic conditions. Immunocolocalization studies identified macrophages as the predominant source of increased PAI-1 within hypoxic lung. Using a transformed murine macrophage line, striking induction of PAI-1 transcripts occurred under hypoxic conditions, due to both increased de novo transcription as well as increased mRNA stability. Consistent with an important role of the fibrinolytic system in hypoxia-induced fibrin accumulation, PAI-1 $+/+$ mice exposed to hypoxia exhibited increased pulmonary fibrin deposition based upon a fibrin immunoblot, intravascular fibrin identified by immunostaining, and increased accumulation of ${ }^{125} \mathrm{I}$-fibrinogen/fibrin in hypoxic tissue. In contrast, mice deficient for the PAI-1 gene (PAI-1 - - ) similarly exposed to hypoxic conditions did not display increased fibrin accumulation compared with normoxic PAI-1 $+/+$ controls. Furthermore, homozygous null uPA (uPA $-I-$ ) and tPA (tPA -I-) mice subjected to oxygen deprivation showed increased fibrin deposition compared with wildtype controls. These studies identify enhanced expression of PAI-1 as an important mechanism suppressing fibrinolysis
\end{abstract}

Address correspondence to David J. Pinsky, M.D., Columbia University College of Physicians and Surgeons, Department of Medicine, PH 10 Stem, 630 W. 168th St., New York, NY 10032. Phone: 212-3056071; FAX: 212-305-7638; E-mail: djp5@columbia.edu

Received for publication 2 April 1997 and accepted in revised form 9 July 1998.

J. Clin. Invest.

(C) The American Society for Clinical Investigation, Inc. 0021-9738/98/09/0919/10 \$2.00

Volume 102, Number 5, September 1998, 919-928

http://www.jci.org under conditions of low oxygen tension, a response which may be further amplified by decreased expression of plasminogen activators. Taken together, these data provide insight into an important potential role of macrophages and the fibrinolytic system in ischemia-induced thrombosis. $(J$. Clin. Invest. 1998. 102:919-928.) Key words: hypoxia • fibrinolysis $\bullet$ plasminogen activator inhibitor-1 $\bullet$ plasminogen activator $\bullet$ transgenic mice

\section{Introduction}

Tissue oxygen concentrations decline rapidly during a period of interrupted blood flow, which, if severe enough, can modulate the phenotype of cells of the vascular wall to trigger thrombosis $(1,2)$. A decline in the $\mathrm{pO}_{2}$ within the venous valve pocket is associated with fibrin accumulation on the venous valve cusps, which may be the progenitor of venous thrombosis accompanying prolonged venous stasis (1). The molecular basis for the prothrombotic diathesis associated with oxygen deprivation is only recently coming to light, with many cells of the vascular wall acting together to promote local thrombosis. Hypoxia-induced modulation of the endothelial phenotype tips the preponderance of anticoagulant mechanisms characteristic of quiescent endothelium towards diverse prothrombotic mechanisms (3-6). Mononuclear phagocytes (MPs) ${ }^{1}$ also appear to have a central role in hypoxia-induced thrombosis; mice exposed to low ambient oxygen concentrations exhibit monocyte recruitment, local tissue factor expression, and thrombosis (7).

Our studies have been designed to dissect mechanisms underlying vascular fibrin deposition associated with oxygen deprivation. Since net accrual of fibrin results from both increased fibrin formation as well as diminished fibrin dissolution, it is likely that enhanced procoagulant activity and inhibition of fibrinolysis act in concert to augment the formation of thrombus. In support of this view, ongoing local fibrinolysis prevented fibrin accumulation in some tissues despite tissue factor induction in a murine sepsis model (8). Our previous work demonstrated that mice placed in an hypoxic environment exhibit a propensity for intravascular fibrin deposition which was inhibited by administration of a functionally blocking anti-tissue factor antibody (7). These data indicate that vascular adaptive mechanisms triggered by hypoxia include modulation of cellular cofactors critical for regulation of coagulation, suggest-

1. Abbreviations used in this paper: ${ }^{125} \mathrm{I}-\mathrm{FIB},{ }^{125} \mathrm{I}$-labeled fibrinogen/fibrin; MP, mononuclear phagocyte; PAI-1, plasminogen activator inhibitor-1; tPA, tissue-type plasminogen activator; uPA, urokinasetype plasminogen activator. 
ing the importance of analyzing the impact of oxygen deprivation on the fibrinolytic system. However, studies of fibrinolytic mechanisms in hypoxic endothelial cells have not provided a clear picture. Human umbilical vein cells exposed to anoxic conditions demonstrate no change in levels of tissue-type plasminogen activator (tPA) or plasminogen activator inhibitor-1 (PAI-1) (9), although reoxygenation was associated with decreased mRNA and activity of both related to the duration of antecedent hypoxic exposure. In contrast, other studies have shown that PAI-1 mRNA is increased in endothelial cells (with an inhibition of fibrinolysis) after $24 \mathrm{~h}$ of exposure to an ambient oxygen concentration of 40 Torr (10).

These studies were undertaken to test the hypothesis that hypoxia suppresses the fibrinolytic potential of MPs, which, taken together with hypoxia-mediated triggering of the procoagulant pathway, amplifies the subsequent accumulation of fibrin. We have focused primarily on the role of PAI-1, a 52-kD serine protease inhibitor which serves as the major plasma inhibitor of tPA or urokinase-type plasminogen activator (uPA). Binding of active PAI-1 with its cognate proteases inhibits their activating the zymogen plasminogen to form plasmin, thereby inhibiting fibrinolysis (11). Our results show coordinated induction of PAI-1 and suppression of plasminogen activators in hypoxic lung, as well as in a transformed monocyte line in vitro. As parallel induction of PAI-1 and inhibition of plasminogen activator gene expression can profoundly inhibit fibrinolysis, these studies could have important implications for the pathogenesis of diseases associated with hypoxemia, such as venous thrombosis, myocardial infarction, and stroke.

\section{Methods}

Macrophage cell culture. RAW cells (a transformed murine macrophage cell line) were obtained from the American Type Culture Collection (Rockville, MD) and grown in RPMI supplemented with 10\% FCS (Hyclone Labs, Logan, UT) and penicillin-streptomycin (50 U/ml and $5 \mu \mathrm{g} / \mathrm{ml}$, respectively). When RAW cells achieved confluence, experiments were performed by washing cells three times with serum-free medium, and then placing them in either a standard cell culture incubator $\left(37^{\circ} \mathrm{C}, 5 \% \mathrm{CO}_{2}\right)$, or a similar incubator within an hypoxia chamber. This environmental chamber (Coy Laboratory Products, Ann Arbor, MI) provides a controlled temperature $\left(37^{\circ} \mathrm{C}\right)$ and a humidified anoxic atmosphere, which results in an oxygen tension in the culture medium of 14-18 Torr. Use of this chamber for cell culture experiments has been described previously $(5,7,12,13)$.

RNA extraction and Northern blot analysis. To detect PAI-1 transcripts, total RNA was extracted from RAW cells or freshly harvested murine tissue using the RNA STAT-60 total RNA isolation reagent (Tel-Test "B", Inc., Friendswood, TX). RNA was size fractionated on a $0.8 \%$ agarose gel containing $2.2 \mathrm{M}$ formaldehyde and transferred overnight to nylon (Duralon-UV; Stratagene, La Jolla, CA) membranes with $10 \times$ SSC buffer by capillary pressure. PAI-1 transcripts were detected using a murine PAI-1 cDNA probe (the plasmid, containing a pBS vector and a 3,014-bp insert was generously provided by M. Cole). The PAI-1 cDNA, consisting of a 775-bp DNA fragment in the PAI-1 encoding region, was prepared by PvuII and Xho1 digestion of the plasmid DNA, and was purified using a QIAEX II gel extraction kit (QIAGEN Inc., Chatsworth, CA). This fragment was used as a cDNA probe after ${ }^{32} \mathrm{P}$-random primer labeling (Prime-It RmT; Stratagene) with $\left[\alpha{ }^{32} \mathrm{P}\right] \mathrm{dCTP}$. After prehybridization and hybridization using QuikHyb hybridization solution (Stratagene), the blots were washed two times at room temperature with $2 \times \mathrm{SSC} / 0.1 \% \mathrm{SDS}$, followed by a $60^{\circ} \mathrm{C}$ wash with $0.1 \times \mathrm{SSC} /$ $0.1 \%$ SDS. Blots were developed with X-Omat AR film exposed with light screens at $-80^{\circ} \mathrm{C}$ for $3 \mathrm{~d}$. Blotting procedures for tPA were performed as described for PAI-1, except that the tPA probe was a murine cDNA fragment (14) comprised of a 2.5-kb insert from a pKS +/plasmid vector, obtained after EcoR1 digestion (plasmid was generously provided by Dr. A. Clowes, University of Washington). Blots for uPA were performed using a murine cDNA obtained from the American Type Culture Collection, comprised of a 1.5-bp insert digested from a pEMBL8 plasmid vector using pST1. For all blots, $\beta$-actin was used as a control to confirm equal lane loading.

$m R N A$ stability and nuclear run-on analyses. PAI-1 mRNA stability was examined as follows. RAW cells were plated in 150-mm petri dishes, and, after a fresh change of medium, they were exposed to either a 4-h period of normoxia or hypoxia at which time point actinomycin D (5 $\mu \mathrm{g} / \mathrm{ml}$; Sigma Chemical Co., St. Louis, MO) was added to inhibit further mRNA transcription. Subsequently, cells were collected at the indicated times and RNA was prepared for Northern blotting, performed as described above. Transcriptional analysis was performed in separate experiments as follows. RAW cells were plated in 150-mm dishes and exposed to either normoxia or hypoxia for $4 \mathrm{~h}$, after which nuclei were isolated and in vitro transcription performed. Immediately after normoxic or hypoxic exposure, cultures were washed twice with ice-cold PBS, lysed in NP-40-containing buffer (Tris/ $\mathrm{HCl}, 10 \mathrm{mM}, \mathrm{pH}$ 7.4; NaCl, $10 \mathrm{mM} ; \mathrm{MgCl}_{2}, 3 \mathrm{mM}$; NP-40, $0.5 \%$ ), incubated on ice for $5 \mathrm{~min}$, and centrifuged at $500 \mathrm{~g}$ for $5 \mathrm{~min}$. Nuclei were washed in lysis buffer, resuspended in storage buffer $(0.2$ $\mathrm{ml}$; Tris/HCl, $50 \mathrm{mM}, \mathrm{pH}$ 8.3; glycerol, $40 \% ; \mathrm{MgCl}_{2}, 5 \mathrm{mM}$; EDTA, $0.1 \mathrm{mM}$ ), and kept at $-80^{\circ} \mathrm{C}$ before use. For in vitro transcription, the nuclei from normoxic or hypoxic MPs $\left(0.6-1 \times 10^{7}\right)$ were thawed and mixed with equal volume of reaction buffer (Tris/ $\mathrm{HCl}, 10 \mathrm{mM}, \mathrm{pH}$ $8.0 ; \mathrm{MgCl}_{2}, 5 \mathrm{mM} ; \mathrm{KCl}, 300 \mathrm{mM}$ ) containing $1 \mathrm{mM}$ each of ATP, CTP, and GTP, and $\left[\alpha{ }^{32} \mathrm{P}\right]$ UTP $(200 \mu \mathrm{Ci} ; 3,000 \mathrm{Ci} / \mathrm{mmol}$; Amersham, Arlington Heights, IL). The reaction mixture was incubated at $30^{\circ} \mathrm{C}$ for $30 \mathrm{~min}$, and ${ }^{32} \mathrm{P}$-labeled RNA was then isolated and precipitated using RNA STAT-60 total RNA isolation reagent (Stratagene). RNA was hybridized to linearized plasmid DNA (PAI-1 and $\beta$-actin), and immobilized on nitrocellulose membranes for $36 \mathrm{~h}$ at $65^{\circ} \mathrm{C}$. Filters were washed in SSC $(2 \times)$ at $65^{\circ} \mathrm{C}$ three times for $30 \mathrm{~min}$ each and exposed to Kodak x-ray film. For the mRNA stability assays, blots were scanned into a Macintosh 8500 computer and NIH Image software was used to calculate the density of each band relative to the corresponding $\beta$-actin band, and the slope of the resulting time-dependent decay of mRNA calculated for each condition by linear regression.

PAI-1 ELISA. Levels of PAI-1 antigen were quantified by a sandwich ELISA, similar to previously described procedures (15). Polystyrene microtiter plates were coated with $100 \mu \mathrm{l}$ of a rabbit polyclonal anti-mouse PAI-1 IgG (American Diagnostica, Greenwich, CT) at a concentration of $20 \mu \mathrm{g} / \mathrm{ml}$, prepared in $50 \mathrm{mM}$ bicarbonate buffer ( $\mathrm{pH} 9.5)$ consisting of $\mathrm{Na}_{2} \mathrm{CO}_{3}(1.59 \mathrm{~g}), \mathrm{NaHCO}_{3}(2.93$ $\mathrm{g}), \mathrm{NaN}_{3}(0.2 \mathrm{~g})$, and double distilled water to 1 liter. After allowing the plate to remain at $4^{\circ} \mathrm{C}$ overnight, the plate was washed four times with washing buffer (PBS with $0.05 \%$ Tween 20), blocked with 200 $\mu \mathrm{l} /$ well of blocking buffer (bicarbonate buffer with $1 \%$ BSA), and then washed four times with washing buffer. Sample (or positive control, consisting of rat PAI-1; American Diagnostica) was added (200 $\mu \mathrm{l} /$ well), incubated at room temperature for $5 \mathrm{~h}$, and then washed four times with washing buffer. Plates were further prepared by adding $200 \mu \mathrm{l} /$ well of rabbit anti-mouse PAI-1 $\operatorname{IgG}(5 \mu \mathrm{g} / \mathrm{ml})$ which was biotinylated using the ECL protein biotinylation module (Amersham). After washing four times with washing buffer, ExtrAvidin Peroxidase (Sigma; diluted 1:1,000 in an assay buffer consisting of PBS [pH 7.4], BSA [0.1\%], and Tween 20 [0.5\%]) was added to each well $(200 \mu \mathrm{l} /$ well). Plates were then developed using $200 \mu \mathrm{l} /$ well of freshly prepared developing solution (in $25 \mathrm{ml}$ of $50 \mathrm{mM}$ citrate phosphate buffer, $\mathrm{pH} 5.3,5 \mathrm{mg}$ of 2,2'-azinobis-(3-ethyl-benzthiazoline-6sulphuric acid [Sigma] and $15 \mu \mathrm{l}$ of $30 \% \mathrm{H}_{2} \mathrm{O}_{2}$ were added). Plates were further incubated to allow color development, followed by termination of the reaction with $1.2 \mathrm{~N} \mathrm{H}_{2} \mathrm{SO}_{4}(50 \mu \mathrm{l} /$ well $)$. Absorbance was read at $405 \mathrm{~nm}$, and the detection limit in this assay was $0.32 \mathrm{pg} /$ 
$\mathrm{ml}$. Experiments were performed in duplicate, with results expressed as means \pm SEM.

PAI-1 activity assay. Plasminogen activator inhibitor activity was determined by a functional rate assay described by Ranby et al. (16), and its adaptation to plasma samples, as described by Wiman et al. (17). In brief, samples from normoxic or hypoxic conditions were added to reaction mixture containing a known quantity of tPA, soluble fibrin (Desafib; American Diagnostica), and a plasmin substrate (Spectrozyme PL; American Diagnostica). Plasmin generated by the reaction of tPA and fibrin cleaves the Spectrozyme substrate to generate a yellow color, which can be measured at OD $405 \mathrm{~nm}$. PAI-1 activity is expressed as the amount of PAI-1 which inhibits 1 IU of tPA.

Immunohistochemistry. Animals were humanely killed immediately upon removal from the hypoxic environment, and lung tissue was fixed by immersion in neutral-buffered formalin (10\%), and embedded in paraffin by standard procedures. Sections were rehydrated and blocked with PBS containing BSA (1\%) and normal goat serum (4\%). For detecting PAI-1, sections were incubated with rabbit antirat PAI-1 (1:50 dilution, $40 \mathrm{~min}$ at $\left.37^{\circ} \mathrm{C}\right)$. Primary antibody was revealed using a goat anti-rabbit IgG avidin-biotin-conjugated system, as per the manufacturer's instructions (Sigma), with 3-amino-9-ethylcarbazole as chromogen. To ascertain that the cells which expressed PAI-1 were indeed MPs, adjacent sections were stained using similar procedures. However, instead of using the anti-rat PAI-1 primary antibody, a rat anti-mouse monoclonal antibody against the MP antigen F4/80 (18) (Caltag Laboratories, South San Francisco, CA) was used. For detecting fibrin, sections were stained with a rabbit antibody raised to rat fibrin monomer which is reactive to fibrin and fibrinogen (anti-rat fibrin IgG, $50 \mu \mathrm{g} / \mathrm{ml}$, provided by Dr. Jef Emeis) (19). Sites of primary antibody binding were visualized with a peroxidase-conjugated secondary antibody, goat anti-rabbit IgG (Sigma).

In vivo hypoxia. Mice were exposed to normobaric hypoxia using a custom-designed, computer-controlled environmental chamber which regulates ambient temperature, humidity, and gas composition. Oxygen concentration is controlled by introducing small amounts of nitrogen as required to maintain oxygen concentration within a narrow pre-set range, using a solenoid triggered by an analogue signal generated by an oxygen sensor (Horiba Instruments, Ann Arbor, MI). A series of scrubbers removes carbon dioxide and gaseous nitrogenous wastes. Ambient oxygen was maintained between 5 and $6 \%$ for all experiments throughout the indicated durations, the lowest sublethal levels which could be achieved in pilot experiments. Use of this chamber has been described previously $(5,7,12,13)$. Normoxic control animals (not placed in the chamber) were otherwise treated in the same manner. In experiments not using genetically manipulated animals, mice were inbred $\mathrm{C} 57 \mathrm{Bl} / 6 \mathrm{~J}$. For experiments using homozygous deletional mutant mice (PAI-1 -/-, tPA -/-, uPA -/-) $(75,76,139)$, the latter mice and control animals were $50 \% \mathrm{C} 57 \mathrm{Bl} / 6 \mathrm{~J}$ and $50 \% 129$ strain. To determine the effects of hypoxia on PAI-1 expression and fibrin accumulation in vivo, mice were killed at the indicated times. When tissue was prepared for fibrin immunoblotting or immunostaining, mice received intravenous heparin $(10 \mathrm{U} / \mathrm{g})$ immediately before time of killing to block postmortem clotting. These methods have been described previously (7). To detect plasma PAI-1 activity or antigen, blood was obtained by ventricular puncture after ketamine/xylazine anesthesia, immediately before humane killing. Lung tissue was obtained for Northern blotting by snap-freezing tissue in liquid nitrogen immediately after time of killing.

Measurement of hypoxia-induced fibrin accumulation. Previous studies have indicated that fibrin is deposited in the lungs of mice exposed to low ambient oxygen (7). Using these previously validated techniques, fibrin was detected in murine lungs by two methods, one in which the accumulation of radioiodinated fibrinogen/fibrin was measured, and the other in which immunoblots were performed on plasmin-digested tissue to detect a neoepitope associated with the gamma-gamma chain dimer present in cross-linked fibrin (20). In the first assay, mouse fibrinogen was labeled with $\mathrm{Na}^{125} \mathrm{I}$ using the Iodobead method (Pierce, Rockford, IL). Animals were each injected with 50-200 $\mathrm{ng}$ of ${ }^{125} \mathrm{I}$-labeled fibrinogen $(2-6 \mu \mathrm{Ci}$ in $0.2 \mathrm{ml}$ saline $)$. At each time, hypoxic and normoxic experiments were conducted simultaneously, using identical doses of ${ }^{125}$ I-labeled fibrinogen administered by tail vein at the start of the time course. At the conclusion of the time course, mice were immediately killed as described, lungs were harvested, dried, weighed, and radioactivity was counted. Relative deposition of ${ }^{125} \mathrm{I}$ fibrinogen/fibrin $\left({ }^{125} \mathrm{I}-\mathrm{FIB}\right)$ was calculated as the ratio of counts per minute per gram of tissue between hypoxic animals and normoxic controls. Immunoblotting for fibrin was performed using a technique which has been described previously (7). In brief, lung tissue was placed in iced buffer $(0.05 \mathrm{M}$ Tris, $0.15 \mathrm{M} \mathrm{NaCl}$, $500 \mathrm{U} / \mathrm{ml}$ heparin, pH 7.6), followed by homogenization. Plasmin digestion was performed by a modification of the method of Francis (21), in which human plasmin $(0.32 \mathrm{U} / \mathrm{ml}$; Sigma) was incubated with the tissue homogenate, followed by agitation at $37^{\circ} \mathrm{C}$ for $6 \mathrm{~h}$, and subsequent addition of more plasmin $(0.32 \mathrm{U} / \mathrm{ml})$ and further $2 \mathrm{~h}$ of agitation. The mixture was centrifuged at 2,300 $\mathrm{g}$ for $15 \mathrm{~min}$ and the supernatant was recovered. Samples were boiled in reducing SDS sample buffer for $5 \mathrm{~min}$, loaded onto an SDS-PAGE (10\%) gel under reducing conditions at $20 \mu \mathrm{g} /$ protein per lane, subjected to electrophoresis, and electrophoretically transferred to nitrocellulose. Blots were reacted with a polyclonal rabbit anti-human antibody prepared to gamma-gamma chain dimers present in cross-linked fibrin (generously provided by Dr. J. Sobel) (20) followed by horseradish peroxidase-conjugated goat anti-rabbit IgG (Sigma). Final detection of bands was performed using the enhanced chemiluminescent Western blotting system (Amersham, Buckinghamshire, UK).

Data analysis. Results are expressed as means \pm SEM with SEM for ratios calculated as described by Cochran (22). Statistical analysis was performed using the Student's two-tailed unpaired $t$ test for comparisons between two groups, using Statview software. Differences were considered significant if $P \leq 0.05$.

\section{Results}

Studies were performed to characterize the effects of low ambient oxygen tensions on the expression of PAI-1 in vivo. Mice (C57Bl/6J males, 8 wk old) were placed in an environmental chamber which enabled the ambient fraction of inspired oxygen $\left(\mathrm{FiO}_{2}\right)$ to be lowered to $6 \%$, the lowest nonlethal oxygen concentration in preliminary experiments. Exhaled $\mathrm{CO}_{2}$ and ammonia generated by animals/nitrogenous waste were maintained at undetectable levels by a series of scrubber devices as reported previously (23). Under these conditions, mice became tachypneic but appeared otherwise normal. PAI-1 levels in plasma from hypoxic mice were measured by ELISA using a rabbit polyclonal anti-rat PAI-1 primary antibody, which cross-reacts with murine PAI-1. PAI-1 antigen increased in plasma in a time-dependent fashion, rising as early as $4 \mathrm{~h}$ and continuing for up to $16 \mathrm{~h}$ of hypoxic exposure (Fig. $1 \mathrm{~A}$, left). Because PAI-1 can circulate in both active and latent forms (24), plasma PAI-1 activity was measured using a microtiter system which monitors PAI-1-mediated inhibition of plasminogen-activator activity $(16,17)$. These experiments demonstrated a time-dependent increase in plasma PAI-1 activity (Fig. $1 \mathrm{~A}$, right), increasing as early as $4 \mathrm{~h}$ after initiation of hypoxia. Northern blotting of RNA extracted from various tissues demonstrated that the lungs, kidney, and heart showed hypoxia-induced increases in PAI-1 mRNA levels (4.53-fold increase for lungs, 2.10-fold increase for heart, 1.35-fold increase for kidney) (Fig. $1 \mathrm{~B}$ ), suggesting that these organs represented the predominant source of the increased PAI-1 measured in plasma. When lung tissue was examined for evidence of fibrin accumulation under hypoxic conditions, fibrin was 
identified intravascularly by immunohistochemical staining using a primary rabbit antibody raised to rat fibrin monomer (19) which is cross-reactive in mice (7) (Fig. 2).

To identify potential mechanisms underlying intravascular fibrin deposition under hypoxic conditions, and knowing that many cells of the vascular wall synthesize and secrete PAI-1, we examined the effects of hypoxia on PAI-1 synthesis in the richly vascularized lungs. To our surprise, these experiments failed to reveal significant endothelial or vascular smooth muscle PAI-1 immunostaining (Fig. 3, bottom). In contrast, macrophages stained prominently throughout the lungs of mice exposed to hypoxia, but not those of normoxic controls. These cells were identified as macrophages based upon staining of adjacent sections for the MP antigen F4/80 (18) (Fig. 3, top).

These in vivo studies, in addition to those of Chapman et al. (25), in which PAI-1 synthesis was increased in human alveolar macrophages after treatment with lipopolysaccharide, directed our attention to the role of macrophages in hypoxiainduced PAI-1 production. For these experiments, RAW cells (a transformed murine macrophage cell line) were exposed to hypoxic conditions using an in vitro chamber which reduces the $\mathrm{pO}_{2}$ within the cell culture medium to 14-16 Torr, similar to those levels observed under conditions of tissue ischemia (26) as well as those levels known to induce Weibel-Palade body exocytosis (5) and de novo synthesis of growth factors (27) and cytokines (IL-1, IL-6, IL-8) $(23,28-30)$. Under these conditions, cell viability is maintained $(12,28,31)$ and Northern analysis showed increased PAI-1 mRNA in hypoxic RAW cells compared with normoxic controls (Fig. 4 A, left), similar to the increase in PAI-1 mRNA observed in lung taken from hypoxic mice compared with normoxic control lung (Fig. $4 A$, right). When exposed to hypoxia in vitro, RAW cells showed a time-dependent increase in PAI-1 antigen compared with normoxic controls (Fig. $4 \mathrm{~B}$ ). To further investigate mechanisms involved in hypoxia-mediated increase in PAI-1 transcripts, nuclear run-on analysis was performed using nuclei isolated from RAW cells exposed to either a 4-h period of hypoxia or a comparable period of normoxia. These data demonstrate an increased rate of PAI-1 transcription under hypoxic conditions (less than sixfold increase by densitometric analysis) (Fig. 5A), which is likely to be, at least in part, the reason for increased steady-state levels of PAI-1 mRNA in hypoxic RAW cells. When the stability of mRNA was analyzed by adding actinomycin D to cells after $4 \mathrm{~h}$ of hypoxia (to inhibit further transcription), subsequent serial Northern analysis demonstrated that the decay rate of PAI-1 mRNA was retarded by hypoxia (Fig. $5 \mathrm{~B}$ ). These data were quantified by densitometric scanning of the blot and by performing linear regression analysis to determine the slope of the line inscribed by plotting the PAI-1/ $\beta$-actin mRNA ratios as a function of time; the slope of the normoxic PAI- 1 mRNA decay line is -0.098 relative mRNA units/h $(r=0.94)$, which represents $50 \%$ more rapid decay than that seen with hypoxia $(-0.065$ relative mRNA units/h, $r=0.76)$. These more objective data confirm the subjective impression that PAI-1 mRNA appears to decay at a slower rate under hypoxic than under normoxic conditions, contributing to increased PAI-1 mRNA under hypoxic conditions.

Although tPA mRNA is reportedly unchanged after endothelial exposure to anoxia (9) or hypoxia (10), the PAI-1/ tPA antigen ratio appears to be increased (10), which may contribute to the apparent hypofibrinolytic state of endothelial cells exposed to hypoxia in vitro (10). Because no similar data are available for macrophages, and our in vivo experiments suggested macrophages to be the major source of PAI-1 in

\section{A}
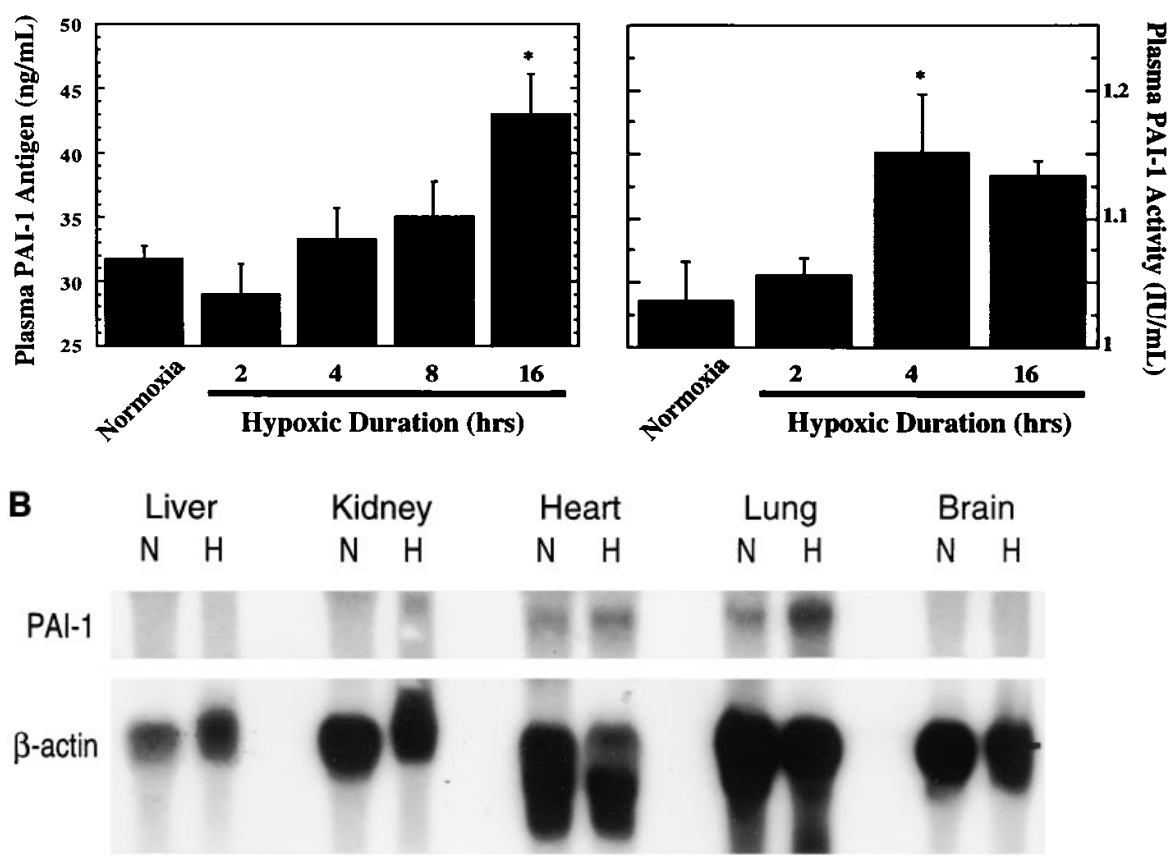

Figure 1. (A) Effect of in vivo exposure to hypoxia on PAI-1 antigen and activity. (Left) PAI-1 antigen. Mice were subjected to either normoxic conditions (leftmost bar) or to normobaric hypoxia $\left(\mathrm{FiO}_{2} 5-6 \%\right)$ for the indicated durations, after which plasma was collected by cardiac puncture and PAI-1 antigen measured using a capture ELISA. Eight mice were sampled for each condition for the duplicate determination of PAI- 1 antigen by ELISA; the means \pm SEM are shown. $* P<0.05$ vs. normoxia. (Right) PAI-1 activity. Mice were subjected to similar conditions as those described above, and plasma was obtained at the indicated times in order to determine PAI- 1 activity. These procedures were performed by a chromogenic assay which measures the ability of PAI-1 to inhibit plasmin generated by the reaction of tPA and fibrin (see Methods). For these experiments, eight mice were used per condition and the values expressed are the means \pm SEM of duplicate determinations. $* P<0.05$ vs. normoxia. (B) Tissue survey of PAI-1 mRNA levels. Northern blots to compare relative levels of PAI-1 mRNA between various or-

gans were performed using tissue obtained from 16-h hypoxia-exposed $\left(\mathrm{FiO}_{2} 5-6 \%\right)$ or normoxia-exposed (control) mice on at least three separate occasions. The blot which is shown demonstrates PAI-1 mRNA levels in the organs of a single animal exposed to either normoxia or a single animal exposed to hypoxia to facilitate comparison between organs. 

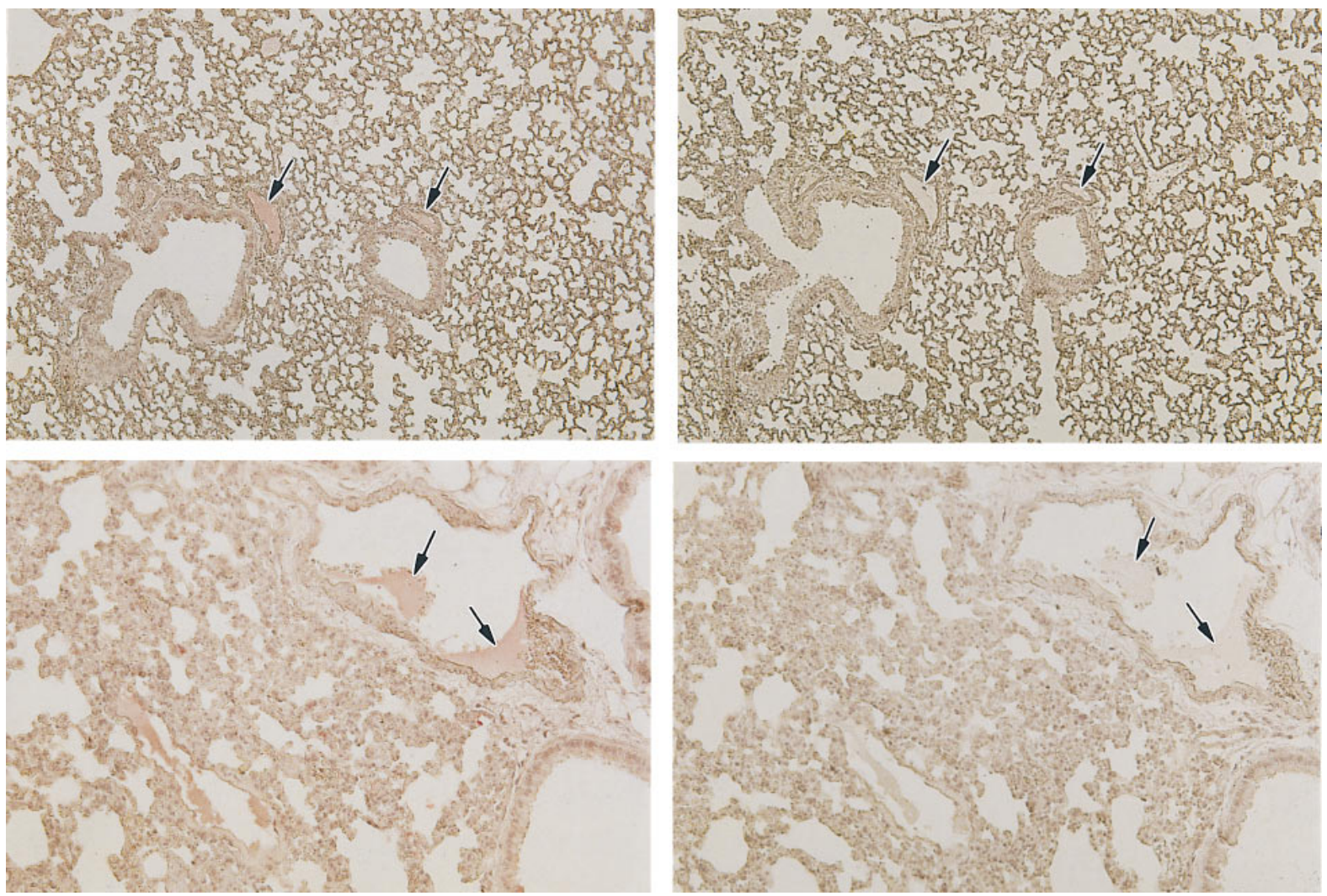

Figure 2. Increased intravascular accumulation of fibrin in a PAI-1 +/+ mouse exposed to $16 \mathrm{~h}$ of hypoxia, demonstrated by immunohistochemistry (with antemortem heparinization to limit postmortem thrombosis). The left panels show the results of immunostaining for fibrin. Arrows point to the intravascular fibrin, which stains pink. The right panels demonstrate the absence of staining in adjacent thin sections when a nonimmune control antibody is used rather than the antifibrin primary antibody, but with otherwise identical staining procedures. Final magnifications, top panels, $\times 500$; bottom panels, $\times 1,000$.

hypoxic lungs, experiments were performed to determine the effects of hypoxia on mRNA levels of tPA and uPA. Mice exposed to hypoxia display a time-dependent decrease in TPA mRNA in lung (Fig. $6 \mathrm{~A}$ ). Similarly, when murine pulmonary tissue was probed for the other major plasminogen activator (uPA), the data were quite similar; uPA transcripts also declined in a timedependent fashion after oxygen deprivation (Fig. $6 B$ ).

These observations of the coincident increase in PAI-1 and decrease in UPA and tPA strongly suggested that the fibrinolytic balance under conditions of hypoxia might be tipped to favor the accumulation of fibrin under conditions of hypoxia. To establish the physiologic relevance of these observations in the pathogenesis of hypoxia-driven fibrin accumulation, three lines of gene-knockout mice, homozygous PAI-1 null (PAI-1 $-/-)(32,33)$, homozygous tPA null (tPA - - -) (34), and homozygous uPA null (uPA -/-) (34), were subjected to oxygen deprivation. Fibrin accumulation was estimated by injection of ${ }^{125}$ I-labeled fibrinogen at the onset of the hypoxic exposure, after which animals were exposed to hypoxia, killed, and the lungs were counted to provide a semiquantitative measure of accumulated fibrin (designated as ${ }^{125}$ I-FIB). Although this technique is associated with some nonspecific background activity, recent studies in our laboratory have demonstrated that changes in ${ }^{125}$ I-FIB accumulation parallel changes in fibrin accumulation in the setting of oxygen deprivation, based on detection of fibrin using specific antibodies or electron microscopy (7). Pilot data indicated that, in control animals, hypoxia resulted in a $<3.5$-fold increase in the deposition of the tracer, in contrast to virtual absent increase in accumulation of ${ }^{125} \mathrm{I}$ IgG (used to monitor changes in vascular permeability) (7). Therefore, for the current experiments, simultaneous experiments were performed in which control and gene-knockout animals were subjected to $16 \mathrm{~h}$ of hypoxia, in order to examine the relative increase in ${ }^{125} \mathrm{I}$-FIB deposition caused by the absence of a gene for a particular fibrinolytic component (data are expressed as relative ${ }^{125}$ I-FIB deposition; therefore, a value of 1 , observed in wild-type mice, represents $<3.5$-fold increase in the hypoxic/normoxic accumulation of ${ }^{125}$ I-FIB). PAI-1 - /mice exposed to hypoxia for $16 \mathrm{~h}$ exhibited decreases in ${ }^{125} \mathrm{I}-$ FIB deposition compared with hypoxic control mice (PAI-1 $+/+; P<0.01$ ) (Fig. 7 A). On the other hand, uPA $-/-$ and tPA $-/-$ mice exposed to similar hypoxic conditions demonstrated significant increases in ${ }^{125} \mathrm{I}$-FIB deposition compared with wild-type controls (uPA $+/+$ and tPA $+/+; P<0.01$ and $P<0.05$, respectively) (Fig. 7, $B$ and $C$ ).

To confirm that fibrinolytic gene knockout mice exhibit altered hypoxia-mediated accumulation of fibrin, immunoblots were performed using plasmin digests of lung tissue from animals which had either been exposed to hypoxia or which were left under normoxic conditions (using the antibody which cross-reacts with a neoepitope present on gamma-gamma dimer of cross-linked fibrin) (20). Immunoblots performed on tissue obtained from wild-type animals exposed to $16 \mathrm{~h}$ of hypoxia showed an intense band, in contrast to a weaker band ob- 
Normoxia
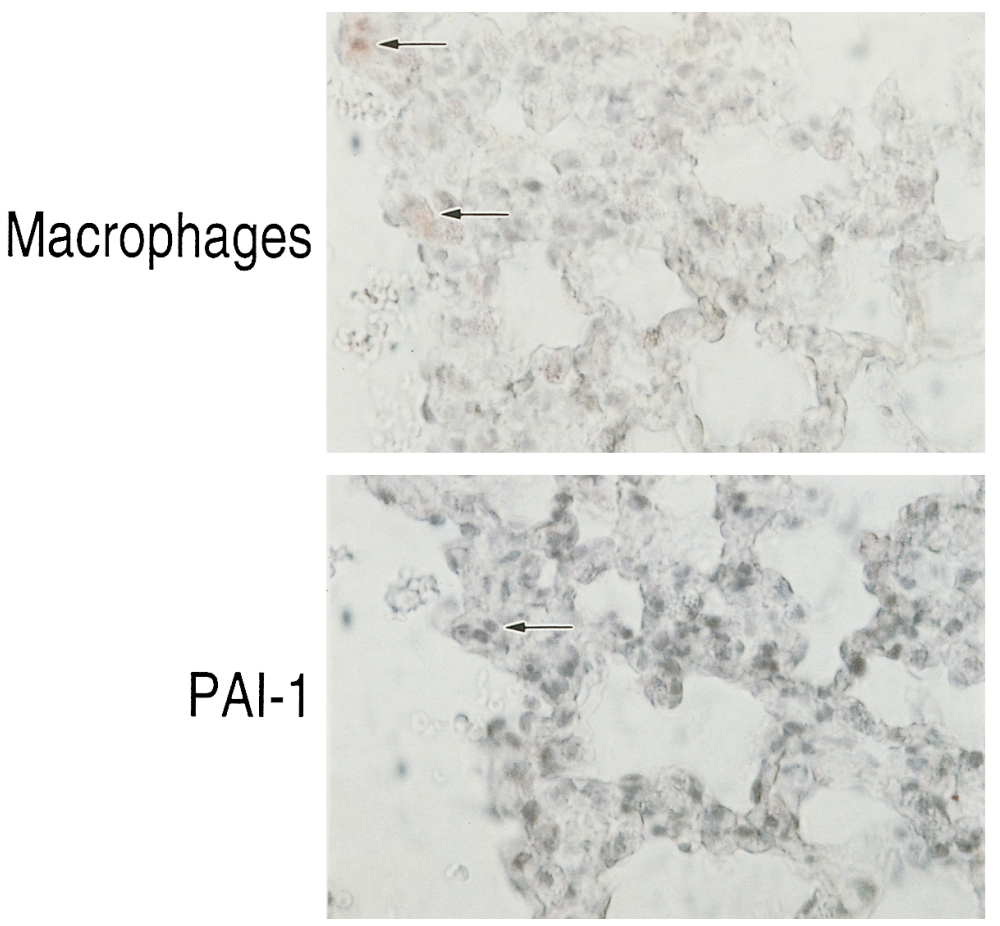

Hypoxia
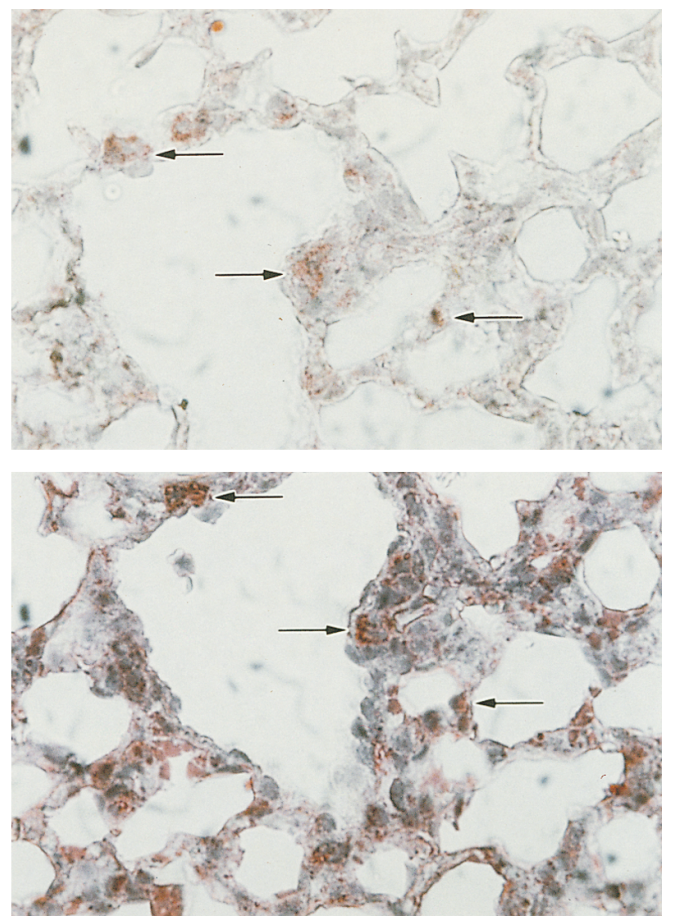

Figure 3. Immunohistochemical colocalization of PAI-1 antigen and MPs in lung tissue from normoxic and hypoxic (PAI-1 +/+) mice. Tissue was obtained from mice under normoxic conditions $(l e f t)$ or after $16 \mathrm{~h}$ of exposure to normobaric hypoxia $\left(\mathrm{FiO}_{2} 5-6 \%\right.$, right $)$. Adjacent sections of paraffin-embedded tissue were immunostained for either PAI-1 (bottom) or the MP marker F4/80 (18) (top) as described in Methods. In hypoxic lung tissue, cells which stain as macrophages (arrows) stain strongly for the PAI-1 antigen (deep russet color). $\times 400$.

served in samples obtained from PAI-1 null animals subjected to identical hypoxic conditions, despite equal loading of the gel $(20 \mu \mathrm{g} / \mathrm{lane}$, Fig. $7 \mathrm{D})$. Animals which were deficient in either tPA or uPA exhibited increased fibrin deposition under hyp- oxic conditions (Fig. 7 D). These experiments confirm that changes in the fibrinolytic balance incited by hypoxic exposure are likely to be of pathologic significance with respect to the accrual of fibrin.
A

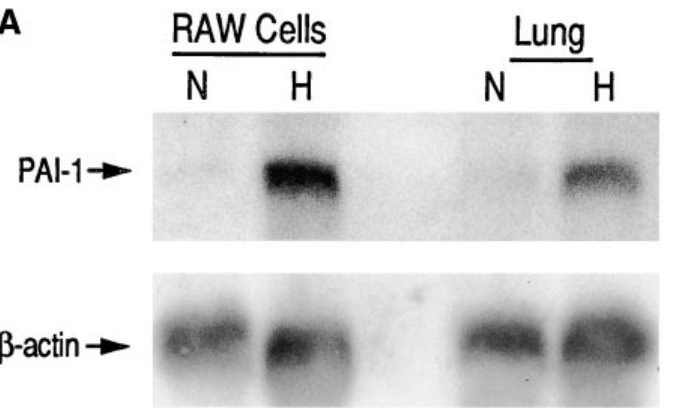

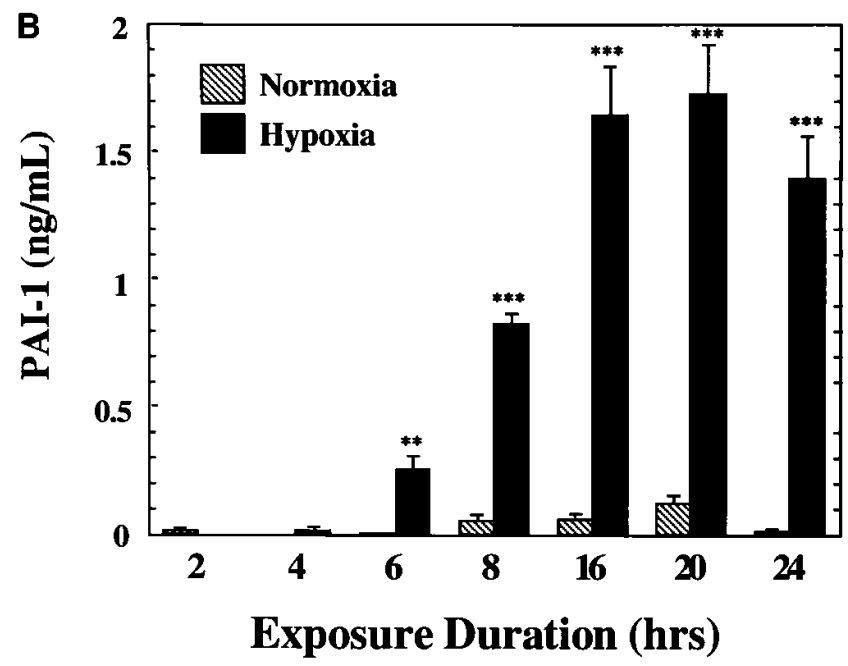

Figure 4. PAI-1 expression under hypoxic conditions. (A) The left panel is a Northern blot demonstrating increased levels of PAI-1 mRNA in RAW cells exposed to $4 \mathrm{~h}$ of hypoxia $(H)$ compared with normoxic control cells $(N)$. The right panel is a Northern blot demonstrating increased levels of PAI-1 mRNA in lung tissue obtained from mice exposed to $16 \mathrm{~h}$ of normobaric hypoxia $\left(H ; \mathrm{pO}_{2} 5-6 \%\right)$ or normoxia $(N)$. (B) PAI-1 antigen expression by RAW cells, as detected using a capture ELISA in which the primary antibody was a rabbit polyclonal anti-rat PAI-1. The exposure duration (to either normoxic or hypoxic conditions after medium change) is shown. Means \pm SEM are shown. ${ }^{* *} P<0.01$, ${ }^{* * *} P<0.001$, hypoxia vs. normoxia. 

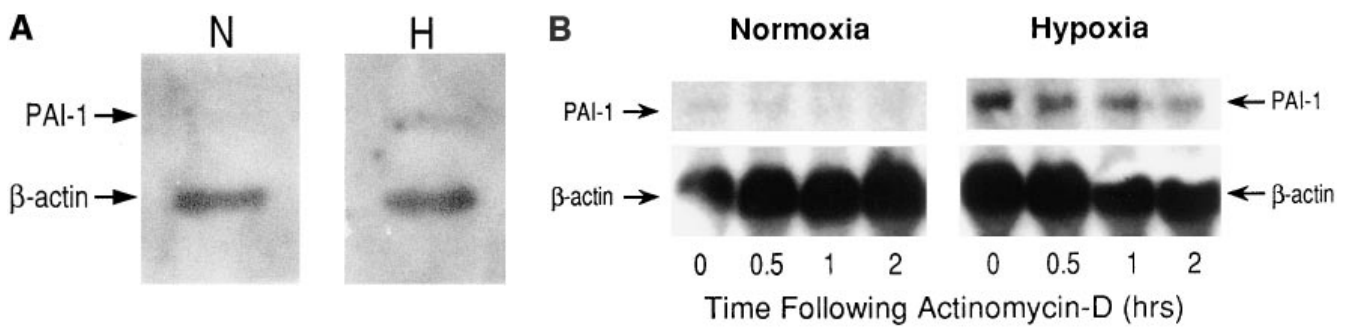

Figure 5. Effect of hypoxia on the transcription and stability of PAI-1 mRNA in RAW cells. $(A)$ Nuclear run-on analysis to assess in vitro transcription of PAI-1 mRNA. Nuclei from $<8 \times 10^{6}$ normoxic $(N)$ MPs (RAW cells) or those exposed to $4 \mathrm{~h}$ of hypoxia $(H)$ were isolated and added to an in vitro transcription reaction mixture containing $\left[\alpha-{ }^{32} \mathrm{P}\right] \mathrm{UTP}$, after which ${ }^{32} \mathrm{P}$-labeled RNA was hybridized to linearized plasmid DNA (PAI-1 and $\beta$-actin) for radiographic detection. The figure shown is representative of three out of four experiments. (B) Analysis of PAI-1 mRNA stability. RAW cells were plated on $150-\mathrm{mm}^{2}$ dishes, and after a fresh change of medium, were either left under normoxic conditions or hypoxic conditions for $4 \mathrm{~h}$, at which time actinomycin D was added to inhibit further mRNA transcription. Subsequently, cells were collected at the indicated times and RNA was prepared for Northern blotting.

\section{Discussion}

A low partial pressure of oxygen represents an important component of the ischemic vascular milieu. Hypoxia has been shown in numerous studies to modulate phenotypic properties of cells of the vascular wall. Endothelial cells subjected to oxygen deprivation display increased levels of neutrophil adhesion molecules at the cellular surface $(4,5)$, synthesize a potent vasoconstrictor (35), and express several proinflammatory cytokines de novo $(23,29,30)$. Recent evidence is emerging that, in concert with the shift towards a procoagulant phenotype, endothelial cells exhibit a diminished fibrinolytic response under conditions of oxygen deprivation, especially when followed by reoxygenation and the attendant production of reactive oxygen intermediates $(9,36)$.

The physiologic relevance of hypoxia-induced modulation of the fibrinolytic response in the pathogenesis of fibrin accumulation is demonstrated by the studies with gene knockout mice. PAI-1-deficient mice, which are apparently healthy but have a mild hyperfibrinolytic state (enhanced lysis of thrombus injected into the jugular vein) (33), demonstrate reduced fibrin accumulation in response to in vivo hypoxic exposure compared with PAI- $1+/+$ controls. In addition, mice deficient for either TPA or UPA show the converse, i.e., increased fibrin accrual after in vivo hypoxic exposure. Our results can be viewed in the context of earlier work performed in rats in which expo- sure to severe oxygen deprivation $\left(\mathrm{F}_{\mathrm{i}} \mathrm{O}_{2} 5 \%\right)$ for $2 \mathrm{~h}$ significantly reduced the fibrinolytic activity of aortic tissue (37), although more modest levels of hypoxemia had the opposite effect. As these and the current experiments were performed using severe hypoxic conditions for periods exceeding $30 \mathrm{~min}$, they do not contradict prior studies in humans, in which modest levels of hypoxia of rapid onset and brief duration caused a decrease in euglobulin lysis time $(38,39)$ yet at the same time caused an increase in the release of Factor VIII coagulant activity and beta thromboglobulin (39). Taken together, the data from these prior experiments and from our own work suggest that in order for hypoxemia to reduce local fibrinolytic activity, hypoxemia must be profound and must occur in a time frame of sufficient duration to permit the transcription and translation of new genes. Given this, it is likely that there is an important role of the fibrinolytic system in fibrin accumulation accompanying severe hypoxemia, and it may help to explain the in vivo observation that hypoxemia associated with venous stasis causes fibrin deposition on venous valve cusps (1). In addition, these observations are likely to be of pathophysiological significance for a wide range of conditions associated with tissue ischemia, including myocardial infarction and stroke.

There is a great deal of overlap between the vascular responses to oxygen deprivation and to sepsis. Hypoxia induces endothelial cell IL-1, IL-6, and IL-8 synthesis, similar to cytokine induction seen in the septic state. The data presented here
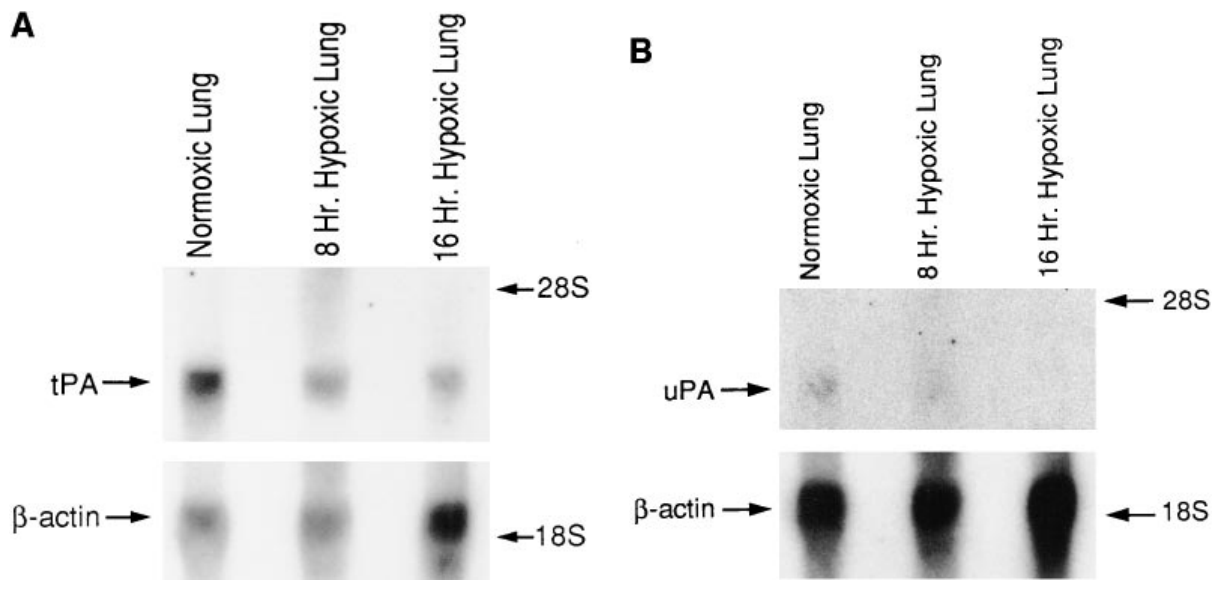

Figure 6. Effect of hypoxia on tPA and uPA mRNA levels in mice in vivo. Mice were exposed to normobaric hypoxia (ambient oxygen was maintained between 5 and $6 \%$ using a computer-controlled environmental chamber). Normoxic control animals (not placed in the chamber) were otherwise treated in the same manner. After the indicated exposure duration, lung tissue was rapidly harvested, snap-frozen in liquid nitrogen, and total RNA was extracted. Size fractionation of RNA was performed by agarose gel electrophoresis, after which Northern blots were probed using cDNA probes for murine tPA $(A)$ or uPA $(B)$. Blots were stripped and then probed with a cDNA for $\beta$-actin, in order to confirm equal loading of lanes. 

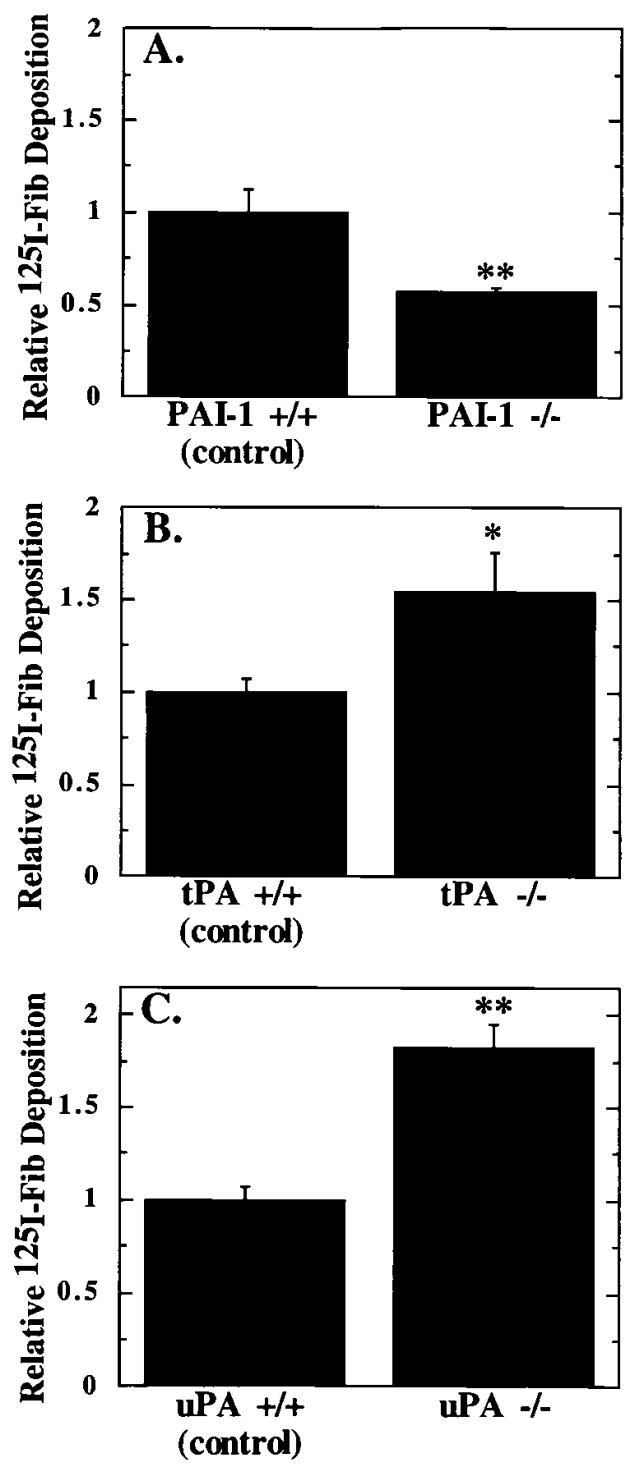

D

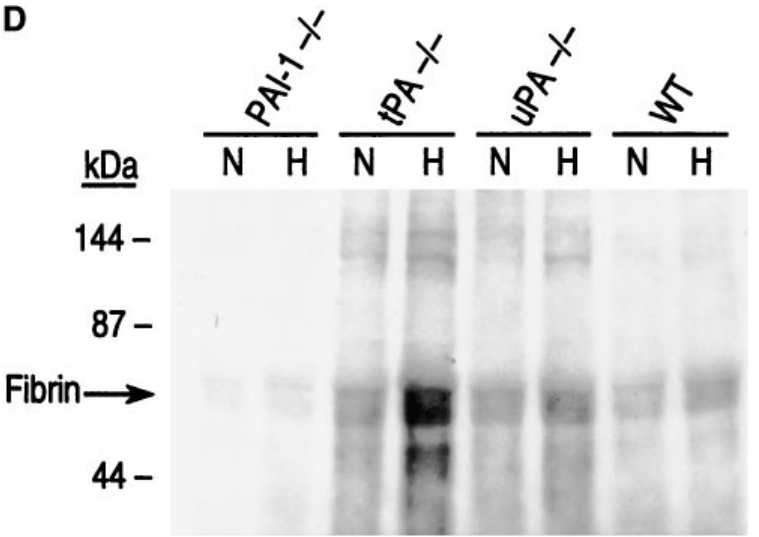

Figure 7. Effect of deletion of either the PAI-1 gene, the tPA gene, or the uPA gene on the hypoxia-induced accumulation of ${ }^{125}$ I-FIB. At the onset of the 16-h hypoxic period, ${ }^{125}$ I-labeled murine fibrinogen was injected into control mice or mice which were homozygous null for either $(A)$ the PAI-1 gene, $(B)$ the tPA gene, or $(C)$ the uPA gene. Relative deposition of ${ }^{125}$ I-FIB was calculated as the ratio of counts per minute per gram of tissue between hypoxic experimental and control animals, with a relative value of 1 representing an $\sim 3.5$ fold increase in the hypoxic/normoxic accumulation of ${ }^{125} \mathrm{I}-\mathrm{FIB}$; the demonstrate that hypoxia also induces PAI-1 expression in hypoxic tissues, which is similar to the clinical situation during sepsis, characterized by a prothrombotic tendency with markedly elevated levels of PAI-1 (40). Treatment of rats with endotoxin results in decreased $\mathrm{PA}$ activity and increased PAI-1 expression in several tissues, including aorta, with tPA activity decreasing due to a shift in the balance between tPA and PAI-1 (41, 42). TNF not only decreases endothelial anticoagulant properties by reducing thrombomodulin expression $(3,43)$, but increases PAI-1 expression in human umbilical vein endothelial cells in vitro (44). In addition, hypoxic endothelial cells secrete IL- $1 \alpha$, which can stimulate the proinflammatory response and cause increased PAI-1 expression in human umbilical vein endothelial cells in vitro (45-47), although IL-1 and TNF appear not to be necessary for PAI-1 induction (48).

Although cytokine generation may augment PAI-1 production after a period of hypoxia, increased PAI-1 expression appears to be a primary event, based upon several lines of evidence. Although cytokines such as TNF and IL-1, which may be elevated in the hypoxic milieu, could potentially decrease endothelial fibrinolytic activity $(45-47,49)$, inhibition of these cytokines does not alter the increased PAI-1 expression seen in response to endotoxin administration in vivo (48). Although experiments in which tissues are exposed to brief hypoxic perfusion (50) or profound peripheral ischemia (infrarenal aortic cross-clamping [51]) show an early (within $30 \mathrm{~min}$ ) increase in plasminogen activator release, there appears to be a subsequent increase in PAI-1 gene expression by $2 \mathrm{~h}$ (51). This early induction of PAI-1 is unlikely to be secondary to cytokine production, as endothelial cells subjected to hypoxia demonstrate increased production of cytokines at later time points. Macrophages, the principal cells which produce PAI-1 in response to hypoxia in the lungs, demonstrate IL-1 synthesis in response to hypoxia after $9 \mathrm{~h}$ (28) (they do not make TNF under these conditions; Stern, D.M., unpublished observation), also suggesting that autocrine production of proinflammatory cytokines is not likely to be primarily responsible for hypoxiadriven PAI-1 expression.

The data shown in this work indicate that both PAI-1 antigen and activity levels are increased in the plasma of hypoxic animals. Although significant increases in PAI-1 were detected at earlier time points with the activity assay than with the antigen assay, this may reflect PAI-1 latency and idiosyncrasies of the in vitro assay systems, or alternatively, may reflect the fact that other plasminogen activator inhibitors exist in plasma. However, these other inhibitors generally represent a minor contribution to overall plasminogen activator inhibitor activity. Although the net increase in PAI-1 antigen and activity detected in plasma of hypoxic animals may be derived from multiple sources, our data indicate that hypoxia-enhanced PAI-1

modulating effect of a given gene on the hypoxia-induced accumulation of ${ }^{125}$ I-FIB deposition is shown. For these experiments, the numbers of animals were seven (PAI-1 null), five (uPA null), six (tPA null), and six for each of the wild-type control mice under hypoxic conditions. Means \pm SEM are shown, with $* P<0.05$ vs. control, and $* * P<0.01$ vs. control. $(D)$ Effect of PAI-1, tPA, or uPA genes on hypoxia-induced fibrin accumulation as detected by immunoblotting for fibrin, using plasmin digests of lung tissue taken from wild type $(W T)$ or PAI-1, tPA, or uPA null $(-/-)$ animals exposed to $16 \mathrm{~h}$ of hypoxia or normoxia, as indicated. 
expression is most accentuated in lung, suggesting that the fibrinolytic potential of hypoxic lung is especially likely to be compromised. Although many cells are capable of synthesizing PAI-1 (52), within the lung, MPs appear to be the principal cell type responding to oxygen deprivation by upregulating PAI-1 expression. In the experiments shown here (Fig. 3), the majority of cells which stain for PAI-1 also stain for F4/80 (and hence are macrophages). However, additional cell types in the lung also appear to stain for PAI-1 (Fig. 3, bottom right). This suggests that although MPs are the predominant cellular source for hypoxia-induced PAI-1 in the lungs, they are not likely to be the sole source.

Because our in vivo studies point strongly to macrophages both within the alveolus and within the vasculature as the chief source of PAI-1 in hypoxic murine lung, confirmation of hypoxia-induced PAI-1 mRNA and protein expression was demonstrated using the RAW macrophage cell line. Although endothelial cells may be the major source of PAI-1 under basal conditions (53), both a human macrophage cell line (U937 cells) as well as pulmonary macrophages obtained by bronchoalveolar lavage synthesize PAI-1 in vitro in response to exogenous stimuli, particularly proinflammatory agents such as lipopolysaccharide (54). The finding that tissue-based macrophages may modify the vascular milieu under hypoxic conditions in a physiologically important way is not surprising, given that macrophages can exert important paracrine effects on endothelial cells. Macrophages augment endothelial cell growth and angiogenesis under hypoxic conditions by secreting acidic and basic fibroblast growth factors (27), as well as by expressing tissue factor (7), the latter suggesting a potentially important role of macrophages in the accumulation of fibrin under ischemic conditions. Accumulation of fibrin is likely to be an important first step in matrix formation to enable new vessel ingrowth. The important recent observations concerning the role of macrophage expression of $\mathrm{uPA} / \mathrm{tPA}$ receptors that appear to participate in cellular/matrix adhesion $(55,56)$ suggests that PAI-1 expression by recruited macrophages may modulate reparative response after tissue injury.

From a teleological point of view, the coordinated induction of PAI-1 and suppression of plasminogen activator (either tPA or UPA) in the postischemic vascular milieu is likely to be important for postischemic angiogenesis, with accumulated fibrin serving to establish a framework for subsequent tissue repair and neovascularization. Data to support this hypothesis derive from the observation that antibody-induced inhibition of tPA activity in a Matrigel model inhibited development of a capillary network, as did addition of transforming growth factor- $\beta$, which decreased tPA and increased PAI-1 levels (56). It appears that natural PA inhibitors function during angiogenesis to protect neovascularized tissues from excess proteolysis (55).

When extracts of normal lung tissue were digested with plasmin and blotted with antifibrin gamma-gamma chain antibody, a band was observed, albeit fainter than that derived from tissue obtained from mice placed in hypoxic conditions. Although it is difficult to rule out postmortem clotting, based on the large amount of heparin administered, we hypothesize that this small amount of fibrin represents that which forms in homeostasis reflecting the continual low-level activity of the procoagulant pathway which is held in check by profibrinolytic and anticoagulant mechanisms. We hypothesize that hypoxia alters the dynamic equilibrium in the vasculature in which thrombosis and fibrinolysis are continually active at low levels
(57). Hypoxia would appear to disrupt this equilibrium by accelerating prothrombotic processes, such as induction of monocyte tissue factor (7), while at the same time amplifying fibrin accumulation by coordinated induction of PAI-1 and suppression of PA expression. Similar processes are likely to occur in ischemic tissue, thereby providing the fibrin stroma which may then serve as a matrix for subsequent capillary ingrowth and tissue repair. The role of macrophages in hypoxiainduced thrombosis is becoming increasingly apparent, as they appear to be chief cells augmenting fibrin accrual, and also have an important role in expression of angiogenic factors to promote neovascularization of postischemic tissue.

\section{Acknowledgments}

The authors gratefully acknowledge the expert technical assistance of $\mathrm{Mr}$. Yu-Shan Zou with the immunohistochemical procedures.

This work was supported in part by grants from the American Heart Association and the Public Health Service (HL-55397, HL40527, PERC). C.A. Lawson is a recipient of a grant from the American Anesthesiology Foundation, and D.J. Pinsky is a Clinician Scientist of the American Heart Association.

\section{References}

1. Hamer, J.D., P.C. Malone, and I.A. Silver. 1981. The $\mathrm{pO}_{2}$ in venous valve pockets: its possible bearing on thrombogenesis. Br. J. Surg. 68:166-170.

2. Malone, P. 1991. A hypothesis concerning the aetiology of venous thrombosis. Med. Hypothesis. 5:189-201.

3. Koga, S., S. Morris, S. Ogawa, H. Liao, J.P. Bilezikian, G. Chen, W.J. Thomson, T. Ashikaga, J. Brett, D.M. Stern, and D.J. Pinsky. 1995. TNF modulate endothelial properties by decreasing cAMP. Am. J. Physiol. 268:C1104-C1113.

4. Pinsky, D.J., S.-F. Yan, C. Lawson, Y. Naka, J.-X. Chen, E.S.J. Connolly, and D.M. Stern. 1995. Hypoxia and modification of the endothelium: implications for regulation of vascular homeostatic properties. Semin. Cell. Biol. 6:283294.

5. Pinsky, D.J., Y. Naka, H. Liao, M.C. Oz, D.D. Wagner, T.N. Mayadas, R.C. Johnson, R.O. Hynes, M. Heath, C.A. Lawson, and D.M. Stern. 1996. Hypoxia-induced exocytosis of endothelial cell Weibel-Palade bodies. A mechanism for rapid neutrophil recruitment after cardiac preservation. J. Clin. Invest. 97:493-500.

6. Pinsky, D.J., and D.M. Stern. 1994. Hypoxia-induced modulation of endothelial cell function. In Reperfusion Injury and Clinical Capillary Leak Syndrome. B. Zikria, M.C. Oz, and R.W. Carlson, editors. Futura Publishing, Armonk, NY. 31-55.

7. Lawson, C.A., S.-D. Yan, S.-F. Yan, H. Liao, G. Chen, J. Sobel, W. Kisiel, D.M. Stern, and D.J. Pinsky. 1997. Monocytes and tissue factor promote thrombosis in a murine model of oxygen deprivation. J. Clin. Invest. 99:17291738.

8. Yamamoto, K., and D.J. Loskutoff. 1996. Fibrin deposition in tissues from endotoxin-treated mice correlates with decreases in the expression of urokinase-type but not tissue-type plasminogen activator. J. Clin. Invest. 97: 2440-2451.

9. Shatos, M.A., J.M. Doherty, D.C. Stump, E.A. Thompson, and D. Collen. 1990. Oxygen radicals generated during anoxia followed by reoxygenation reduce the synthesis of tissue-type plasminogen activator and plasminogen activator inhibitor-1 in human endothelial cell culture. J. Biol. Chem. 265:2044320448.

10. Gertler, J.P., L. Perry, G. L'Italien, N. Chung-Welch, R.P. Cambria, R. Orkin, and W.M. Abbott. 1993. Ambient oxygen tension modulates endothelial fibrinolysis. J. Vasc. Surg. 18:939-945.

11. Collen, D., and H.R. Lijnen. 1992. Fibrin-specific fibrinolysis. Ann. NY Acad. Sci. 667:259-271.

12. Ogawa, S., H. Gerlach, C. Esposito, A. Pasagian-Macaulay, J. Brett, and D.M. Stern. 1990. Hypoxia modulates the barrier and coagulant function of cultured bovine endothelium. J. Clin. Invest. 85:1090-1098.

13. Pinsky, D.J., M.C. Oz, S. Koga, Z. Taha, M.J. Broekman, A.J. Marcus, H. Liao, Y. Naka, J. Brett, P.J. Cannon, et al. 1994. Cardiac preservation is enhanced in a heterotopic rat transplant model by supplementing the nitric oxide pathway. J. Clin. Invest. 93:2291-2297.

14. Rickles, R.J., A.L. Darrow, and S. Strickland. 1988. Molecular cloning of complementary DNA to mouse tissue plasminogen activator mRNA and its expression during F9 teratocarcinoma cell differentiation. J. Biol. Chem. 263: 1563-1569.

15. MacGregor, I.R., and N.A. Booth. 1988. An enzyme-linked immunosor- 
bent assay (ELISA) used to study the cellular secretion of endothelial plasminogen activator-inhibitor (PAI-1). Thromb. Haemost. 59:68-72.

16. Ranby, M., B. Norrman, and P. Wallen. 1982. A sensitive assay for tissue plasminogen activator. Thromb. Res. 27:743-749.

17. Wiman, B., G. Mellbring, and M. Ranby. 1983. Plasminogen activator release during venous stasis and exercise as determined by a new specific assay. Clin. Chim. Acta. 127:279-288.

18. Lee, S.-H., P.M. Starky, and S. Gordon. 1985. Quantitative analysis of total macrophage content in adult mouse tissues. J. Exp. Med. 161:475-489.

19. Emeis, J.J., J. Lindeman, and W. Nieuwenhuizen. 1981. Immunoenzyme histochemical localization of fibrin degradation products in tissues. Am. J. Pathol. 103:337-344.

20. Lahiri, B., J.A. Koehn, R.E. Canfield, S. Birken, and J. Lewis. 1981. Development of an immunoassay for the $\mathrm{COOH}$-terminal region of the gamma chains of human fibrin. Thromb. Res. 23:103-112.

21. Francis, C.W., V.J. Marder, and S.E. Martin. 1980. Plasmic degradation of crosslinked fibrin I. Structural analysis of the particulate clot and identification of new macromolecular-soluble complexes. Blood. 56:456-464.

22. Cochran, W.G. 1977. Sampling Techniques. John Wiley and Sons, New York. 30 pp.

23. Shreeniwas, R., S. Koga, M. Karakurum, D.J. Pinsky, E. Kaiser, J. Brett, B.A. Wolitzky, C. Norton, J. Plocinski, W. Benjamin, et al. 1992. Hypoxiamediated induction of endothelial cell interleukin 1-alpha. An autocrine mechanism promoting expression of leukocyte adhesion molecules on the vessel surface. J. Clin. Invest. 90:2333-2339.

24. Loskutoff, D.J., M. Sawdey, M. Keeton, and J. Schneiderman. 1993. Regulation of PAI-1 gene expression in vivo. Thromb. Haemost. 70:135-137.

25. Chapman, H.A., X.L. Yang, L.Z. Sailor, and D.J. Sugarbaker. 1990. Developmental expression of plasminogen activator inhibitor type 1 by human alveolar macrophages. Possible role in lung injury. J. Immunol. 145:3398-3405.

26. Oz, M.C., H. Liao, Y. Naka, A. Seldomridge, D.N. Becker, R.E. Michler, C.R. Smith, E.A. Rose, D.M. Stern, and D.J. Pinsky. 1995. Ischemiainduced interleukin- 8 release following human heart transplantation: a potential role for endothelial cells. Circulation. 92:II-428-II-432.

27. Kuwabara, K., S. Ogawa, M. Matsumoto, S. Koga, M. Clauss, D.J. Pinsky, L. Witte, J. Joseph-Silverstein, M. Furie, G. Torcia, et al. 1995. Hypoxiamediated induction of acidic/basic fibroblast growth factor and platelet-derived growth factor in mononuclear phagocytes stimulates growth of hypoxic endothelial cells. Proc. Natl. Acad. Sci. USA. 92:4606-4610.

28. Koga, S., S. Ogawa, K. Kuwabara, J. Brett, J.A. Leavy, J. Ryan, Y. Koga, J. Plocinski, W. Benjamin, D.K. Burns, and D.M. Stern. 1992. Synthesis and release of interleukin-1 by reoxygenated human mononuclear phagocytes. J. Clin. Invest. 90:1007-1015.

29. Yan, S.F., I. Tritto, D.J. Pinsky, H. Liao, L. May, and D.M. Stern. 1995. Induction of interleukin 6 (IL-6) by hypoxia in vascular cells: central role of the binding site for nuclear factor-IL-6. J. Biol. Chem. 270:11463-11471.

30. Karakurum, M., R. Shreeniwas, J. Chen, D.J. Pinsky, S.-D. Yan, M. Anderson, K. Sunouchi, J. Major, T. Hamilton, K. Kuwabara, et al. 1994. Hypoxic induction of interleukin-8 gene expression in human endothelial cells. $J$. Clin. Invest. 93:1564-1570.

31. Ogawa, S., R. Shreeniwas, J. Brett, M. Clauss, M. Furie, and D.M. Stern. 1990. The effect of hypoxia on capillary endothelial cell function: modulation of barrier and coagulant function. Br. J. Haematol. 75:517-524.

32. Carmeliet, P., L. Kieckens, L. Schoonjans, B. Ream, A. Van Nuffelen, G. Predergast, M. Cole, R. Bronson, D. Collen, and R.C. Mulligan. 1993. Plasminogen activator inhibitor-1 gene-deficient mice. I. Generation by homologous recombination and characterization. J. Clin. Invest. 92:2746-2755.

33. Carmeliet, P., J.M. Stassen, L. Schoonjans, B. Ream, J.J. van den Oord, M. De Mol, R.C. Mulligan, and D. Collen. 1993. Plasminogen activator inhibitor-1 gene deficient mice. II. Effects on hemostasis, thrombosis, and fibrinolysis. J. Clin. Invest. 92:2756-2760.

34. Carmeliet, P., L. Schoonjans, L. Kieckens, B. Ream, J. Degen, R. Bronson, R. De Vos, J.J. van den Oord, D. Collen, and R.C. Mulligan. 1994. Physiological consequences of loss of plasminogen activator gene function in mice. Nature. 368:419-424.

35. Kourembanas, S., P.A. Marsden, L.P. McQuillan, and D.V. Faller. 1991. Hypoxia induces endothelin gene expression and secretion in cultured human endothelium. J. Clin. Invest. 88:1054-1057.

36. Shatos, M.A., J.M. Doherty, T. Orfeo, J.C. Hoak, D. Collen, and D.C.
Stump. 1992. Modulation of the fibrinolytic response of cultured human vascular endothelium by extracellularly generated oxygen radicals. J. Biol. Chem. 267:597-601.

37. Risberg, B., and B. Stenberg. 1985. Modulation of tissue fibrinolysis from hypoxia and hyperoxia. Thromb. Res. 38:129-136.

38. Magnum, M., R.H. Venable, J.D. Boatwright, and T.B. Cocke. 1987 Hypoxia: a stimulus for tissue plasminogen activator release in humans? Aviat. Space Env. Med. 58:1093-1096.

39. Bartsch, P., A. Haeberli, K. Hauser, A. Gubser, and P.W. Straub. 1988 Fibrinogenolysis in the absence of fibrin formation in severe hypobaric hypoxia. Aviat. Space Env. Med. 59:428-432.

40. Pralong, G., T. Calandra, M.P. Glauser, J. Schellekens, J. Verhoef, F. Bachmann, and E.K. Kruithof. 1989. Plasminogen activator inhibitor-1: a new prognostic marker in septic shock. Thromb. Haemost. 61:459-462.

41. Padro, T., P.H.A. Quax, C.M. van den Hoogen, P. Roholl, J.H. Verheijen, and J.J. Emeis. 1994. Tissue-type plasminogen activator and its inhibitor in rat aorta: effect of endotoxin. Arterioscler. Thromb. Vasc. Biol. 14:1459-1465.

42. Quax, P.H.A., C.M. van den Hoogen, J.H. Verheijen, T. Pedro, R. Zeheb, T.D. Gelehrter, T.J.C. van Berkel, J. Kuiper, and J.J. Emeis. 1990. Endotoxin induction of plasminogen activator and plasminogen activator inhibitor type 1 mRNA in rat tissues in vivo. J. Biol. Chem. 265:15560-15563.

43. Nawroth, P.P., and D.M. Stern. 1986. Modulation of endothelial cell hemostatic properties by tumor necrosis factor. J. Exp. Med. 163:740-745.

44. Martin, N.B., A. Jamieson, and D.P. Tuffin. 1993. The effect of interleukin-4 on tumour necrosis factor-alpha induced expression of tissue factor and plasminogen activator inhibitor-1 on human umbilical vein endothelial cells. Thromb. Haemost. 70:1037-1042.

45. Bevilacqua, M.P., J.S. Pober, G.R. Majeau, R.S. Cotran, and M.A.J. Gimbrone. 1984. Interleukin 1 (IL-1) induces biosynthesis and cell surface expression of procoagulant activity in human vascular endothelial cells. $J$. Exp. Med. 160:618-623.

46. Nachman, R.L., K.A. Hajjar, R.L. Silverstein, and C.A. Dinarello. 1986. Interleukin 1 induces endothelial cell synthesis of plasminogen activator inhibitor. J. Exp. Med. 163:1595-1600.

47. Bevilacqua, M.P., R.R. Schleef, M.A.J. Gimbrone, and D.J. Loskutoff. 1986. Regulation of the fibrinolytic system of cultured human vascular endothelium by interleukin 1. J. Clin. Invest. 78:587-591.

48. Emeis, J.J., R. Hoekzema, and A.F. de Vos. 1995. Inhibiting interleukin-1 and tumor necrosis factor-alpha does not reduce induction plasminogen activator inhibitor type-1 by endotoxin in rats in vivo. Blood. 85:115-120.

49. van Hinsbergh, V.W.M., T. Kooistra, E.A. van den Berg, H.M.G. Princen, W. Fiers, and J.J. Emeis. 1988. Tumor necrosis factor increases the production of plasminogen activator inhibitor in human endothelial cells in vitro and in rats in vivo. Blood. 72:1467-1473.

50. Tappy, L., J. Hauert, and F. Bachmann. 1984. Effects of hypoxia and acidosis on vascular plasminogen activator release in the pig ear perfusion system. Thromb. Res. 33:117-124.

51. Schneiderman, J., Y. Eguchi, R. Adar, and M. Sawdey. 1994. Modulation of the fibrinolytic system by major peripheral ischemia. J. Vasc. Surg. 19: $516-524$.

52. Loskutoff, D.J., M. Sawdey, and J. Mimuro. 1989. Type 1 plasminogen activator inhibitor. Prog. Hemost. Thromb. 9:87-115.

53. Yamamoto, C., T. Kaji, M. Sakamoto, H. Kozuka, and F. Koizumi. 1994. Calcium regulation of tissue plasminogen activator and plasminogen activatorinhibitor-1 release from cultured human vascular endothelial cells. Thromb. Res. 74:163-168.

54. Kassis, J., J. Hirsh, and T.J. Podor. 1992. Evidence that postoperative fibrinolytic shutdown is mediated by plasma factors that stimulate endothelia cell type I plasminogen activator inhibitor biosynthesis. Blood. 80:1758-1764.

55. Bacharach, E., A. Itin, and E. Keshet. 1992. In vivo patterns of expression of urokinase and its inhibitor PAI-1 suggest a concerted role in regulating physiological angiogenesis. Proc. Natl. Acad. Sci. USA. 89:10686-10690.

56. Ito, K., M. Ryuto, S. Ushiro, M. Ono, A. Sugenoya, A. Karaoka, Y. Shibita, and M. Kuwano. 1995. Expression of tissue-type plasminogen activator and its inhibitor couples with development of capillary network by human microvascular endothelial cells on Matrigel. J. Cell. Physiol. 162:213-224.

57. Nossel, H.L. 1981. Relative proteolysis of the fibrinogen B beta chain by thrombin and plasmin as a determinant of thrombosis. Nature. 291:165-167. 